\title{
A Comparative Study on the Chauvinism of Nationalist Discourse in Selected Poems by Mahmoud Darwish, Maya Angelou and Rudyard Kipling
}

\author{
Hussein H. Zeidanin ${ }^{1}$ \\ ${ }^{1}$ Associate Professor of Literature and Literary Criticism, Department of English Language and Literature, Tafila \\ Technical University, Jordan \\ Correspondence: Hussein H. Zeidanin, Associate Professor of Literature and Literary Criticism, Department of \\ English Language and Literature, Tafila Technical University, Jordan.
}

Received: June 22, 2020

doi:10.5430/wjel.v10n2p55
Accepted: September 25, $2020 \quad$ Online Published: September 28, 2020

URL: https://doi.org/10.5430/wjel.v10n2p55

\begin{abstract}
Poststructuralists, such as Foucault, conceived discourse as "a form of power that circulates in the social field and can attach to strategies of domination as well as those of resistance" (Diamond \& Quinby, 1988, p. 185). Discourse denotes a system of thought through which knowledge is produced, truth is constructed and maintained, and power relations are redefined. The current article examines the nationalist discourse disseminated and adopted in selected poems by the Palestinian writer Mahmoud Darwish, African American writer Maya Angelou and British writer Rudyard Kipling. Nationalist discourse, the article argues, usually revives the sense of resistance, self-esteem and pride in the subaltern groups of the colonized and the oppressed but breeds a quest for expansion and domination in the colonizer. It holds overt and covert chauvinistic implications that necessarily deepen interracial conflicts. The chauvinistic aspects associated with the poems include an emphasis on the hierarchy of races, race-based division of the world's continents, and homogeneity of races and cultures. The comparisons the article makes proceed from the essential representation of self and other and the subsequent feelings of disrespect, distrust and fear that characterize the attitudes and perspectives of people identifying with different cultures and homelands. The article questions the dominant narratives underlying national identity in colonial and anti-colonial contexts. It further questions the monolithic concept of home, which nationalists advance to fuel colonial expansion or anti-colonial resistance. The article finds that racial and cultural chauvinism lies at the core of the nationalist discourse the selected poems reproduce.
\end{abstract}

Keywords: anti-colonialism, chauvinism, colonialism, comparative, nationalism

\section{Introduction}

The article critically examines the discourse of nationalism that underlies identity (re)construction in colonial and anti-colonial cultural contexts. Nationalism Edward Said believed "is more and more constraining. In any case, nativism is not the only alternative. There is the possibility of a more generous and pluralistic vision of the world" (Bayoumi, M., \& Rubin A., 2000, p. 303). The vision Edward Said adopted and advanced in his writings lies on the formation of a hybrid cultural identity that deconstructs the nationalist paradigm of cultural homogeneity, coherence and purity. Said added "liberation, and not national independence, is the new alternative, liberation which by its very nature involves, in Fanon's words, a transformation of social consciousness beyond national consciousness" (Bayoumi, M., \& Rubin A., 2000, p. 303). The colonized and oppressed people should accordingly revolt to transform their social conditions and to form a heterogeneous nation-state that defies homogeneity and chauvinism.

On the basis of Said's anti-nationalist sentiments, the article contends that nationalism cultivates chauvinistic conceptions of cultural and racial superiority, and misconstrues identity as monolithic and homogeneous. The sense of identity pride and prejudice nationalism fosters and instills in colonial and anti-colonial subjects is a common chauvinistic aspect the article investigates in Angelou's "Africa", Darwish's "I Come from There", and Kipling's "The White Man's Burden". The poems selected epitomize different types of nationalisms such as colonial nationalism in Kipling's poem and anticolonial nationalism in the poems of Angelou and Darwish. The methodology upon which the poems are analyzed and interpreted is the American School of comparative literature which rejected the principle 
of influence the French School promoted in favor of the principle of parallelism. The Arab American theorist and critic Ihab Hassan (1955) proposed parallelism to gloss over the questions of direct and indirect influence, and alternatively focus on the similarities between the literatures of different peoples with similar social and ideological backgrounds. The thread through which the three poems are interwoven, the article argues, is the chauvinistic tendencies they cultivate. The views of Social Darwinists, Black nationalists and anti-colonialists are of great significance for the critical analysis and reading of the poems. Pertinent to the research problem and objectives are the questions of: To what extent are the speakers chauvinistic? How do they view the relation of the self and the other? How do they view their relationship to homeland, indigenous cultures and languages? What kind of identity do they develop and promote?

\section{Discussion}

This part is organized into three sections, each of which reflects upon the ideological and cultural background of a poet, reviews scholarly articles on his or her poetry, critically investigates the nationalist discourse engendered and revived in the selected poem, and reveals the chauvinistic overtones of the speaker in each poem. The chauvinistic attitudes of the speakers, the article assumes, does not necessarily confirm the chauvinism of the poets, considering the New Critical presumption that the speaker and the poet have different voices and perspectives. The interpretation and analysis of the selected poems will be based more on the voice of the speaker than on the voice of the poet.

\subsection{Rudyard Kipling}

Kipling was a contemporary and fellow citizen of Charles Darwin, whose theory of evolution, survival of the fittest and natural selection laid the ground for social Darwinism. The scientific principles Darwin administered to different species of plants and animals were manipulated by social Darwinists, including Kipling, to explain non-scientific phenomena such as the hierarchy of races, cultures and nations, and to substantiate imperialism and colonialism. Herbert Spencer was a prominent social Darwinist, who used Darwinism to "explain why some races and nations are superior, powerful and civilized while others are inferior, weak, uncivilized and therefore deserve to be exploited" (Offer, 2000, p. 88). Eugenics is considered the most radical form of social Darwinism for its prohibition of intermarriage, which is portended to blur and obliterate the tenuous lines separating naturally superior white from inferior black. War was "nature's way of dominating the unfit" (Perry, M., Chase, M., Jacob, J. R., Daly, J. W., \& Von Laue, T. H., 2013, p. 566) in nations and races' struggle for survival. Superior races accordingly have the right to invade and colonize other inferior races under the pretexts of civilization, progress and modernization.

Informed by the nuances of social Darwinism and colonial nationalism, Kipling's works saturate pro-imperial attitudes and uphold a world ruled by the White man. It is contended that Britain as an imperial power manipulated politics, economics and literature to dominate and exploit its colonies such as India. Kipling perceived imperialism as a project of enlightenment and civilization, which India as a barbarous country direly needed. Kipling's major works of imperialism are Kim, The Man Who Will Be King, and "The White Man's Burden" in which the empire is viewed as an agency of progress and civilization. However, he described natives as "silent and helpless people and calls them as 'the other' to impose the British imperialist control over them. He also believes that the British are rational and capable of true values, while Indians are incapable to rule themselves" (Hanane, 2019, p. 35). In his view, the British Empire sought to enlighten, civilize and humanize primitive savages in the countries it was colonizing in Asia, Africa and Americas.

Kipling's consciousness of India as a country with primitive people and culture formed his prejudices and preconceptions. Kipling lived in the nineteenth-century Britain that was characterized by the rise of social Darwinism, nationalism and modern racism. Kipling's exposures to the writings of nationalists and Darwinists substantiated his pro-imperial attitudes. In his view, "Britain had a specific task to civilize the world and, due to its heritage, it should bring liberty and civilization for other nations" (Šumberová, 2006, p. 14). Kipling further considered the British the legitimate rulers of India, and called the Indians to appreciate the efforts the British civil servants, engineers, and architects exerted to civilize and develop their nation.

Kipling's pro-imperial works supported the British Empire in India. The identity crisis colonial subjects in India underwent resulted from their exposure to the ideology and culture of the empire. The postcolonial identity of the Indians has been constructed in a liminal space marked by ambivalence and hybridity. The endeavors of colonial subjects to adapt the habits, culture, language and values of the colonizer heightened their identity crisis due to their liminal in-between position. Kipling portrayed Indians as "the Other in order to show the supremacy of the British people. He explores the imperfections in the Indian characters by describing them not to be completely reformed from their native behavior" (Ghiasvand, F., \& Bahman Z, 2014, p. 1699). 
The speaker in "The White Man's Burden" preaches to anti-imperialist Americans about the virtues of colonial imperialism to persuade them of accepting and supporting the American colonial endeavors and aims in the Philippines and elsewhere:

$$
\begin{gathered}
\text { Go bind your sons to exile } \\
\text { To serve your captives' need; } \\
\text { To wait in heavy harness } \\
\text { On fluttered folk and wild-- } \\
\text { Your new-caught, sullen peoples, } \\
\text { Half devil and half child. }
\end{gathered}
$$

It is entailed that colonial imperialism should not be viewed as an end by itself but a means to an end. It enables the White man to perform his moral obligations towards his captives (Filipinos). The White man, the speaker believes, is morally obligated to guide the progress of the inferior colonial subjects from savagery to civilization and from damnation to redemption through education and Christianization. The White man also relies on colonial imperialism to

\section{Fill full the mouth of Famine}

\section{And bid the sickness cease.}

Colonial presence supposedly brings peace, food and health to help ease the pain, hunger and fear of the colonized people. It contributes to the modernization of colonies, where new facilities, roads and ports are constructed.

The speaker further proposes that colonial imperialism is a divine burden laid upon the White race to reign and civilize the none White world. It is presumed that the White man is naturally fitter to rule and command than the non-white. Hence, the white should

$$
\begin{gathered}
\text { Take up the White Man's burden- } \\
\text { Have done with childish days- }
\end{gathered}
$$

It is so childish for the White man to disclaim the burden he is supposed to undertake. Repeating the line "Take up the White Man's burden" at the beginning of each stanza in the poem confirms the divinity of colonial conquests, which the White man should pursue with pride and honor. The White man's destiny is to be the savior of the non-white. Hence, he should bring them toward the light of civilization, progress and faith. Losing the non-white to ignorance, famine and ill-health is an immoral choice the speaker forewarns the white not to make.

The speaker's pro-colonial tone implicates a polysemous concept of home. In colonial contexts, the notion of home is not narrowed down to the country, where the White man was born and grew up. Rather, it is expanded to signify the whole globe the White man is entrusted to be a custodian and guardian. America as a rising Empire, therefore, has to

Send forth the best ye breed-

Go bind your sons to exile

It is construed that America should act not as a nation mobilizing troops and civilians only to defend itself against invasion and domination but as an Empire that holds itself responsible for the world's woes and prosperity. Imperial wars, the speaker thinks, are not less holy than self-defense wars because they are waged for good causes. America as an imperial power should consequently send the best of its men to the Philippines, where natives are mired in a swamp of ignorance, poverty and illnesses.

The speaker, likewise, redefines the relationship between the white and the non-white on the ground of imperial rule. He maintains the White man should act as a father figure or an older brother figure to colonial subjects in the non-White world. Patience, forgiveness and humility should inform the way the White man treats his younger brothers and sisters:

\section{Take up the White Man's burden-}

In patience to abide,

To veil the threat of terror

And check the show of pride;

By open speech and simple, 
An hundred times made plain.

In these lines, the White man is asked not to show pride and glory though he has all the reason to feel proud and glorious. He is also advised to speak slowly and use a clear plain language to effectively communicate with the natives. The White man is further expected to forgive the ingratitude, indifference and animosity with which he is treated. The speaker explains that colonization is a thankless tedious duty the White man is singled out to undertake:

Take up the White Man's burden-

And reap his old reward:

The blame of those ye better,

The hate of those ye guard-

The colonizing efforts the White man exerts for the civilization and enlightenment of the non-white are ironically rewarded with protest and hatred. Yet, the White man is supposed to meet ingratitude with patience and forgiveness. He should be as patient as Moses whom the Israelites depreciated his attempts to free them from the oppression of the Pharaohs and turn them from darkness to light:

\section{Why brought ye us from bondage, \\ Our loved Egyptian night?"}

\subsection{Maya Angelou}

Black Nationalist Movements in the United States sought to emancipate African Americans from the legacies of colonization, slavery and segregation through a physical or imaginative return to the African continent. A return to Africa, most African-American writers, artists and intellectuals believed, would satisfy their quest for selfhood, self-esteem and identity, a thing that did not occur. The literature of Harlem renaissance aroused that black nationalist sentiment, to which African Americans were enticed and bewitched. The works of many African American writers, who were able to visit or live in Africa such as Maya Angelou, Ralph Ellison, Martin Luther King, Richard Wright, James Baldwin, among others advocated a physical or imaginative return to Africa.

Black nationalistic conceptions like new black, Black nation, Black identity, Black pride, Black solidarity and Pan-Africanism permeated the anti-racist and anti-colonial poetry and views of Angelou. W. E. B. Du Bois and Marcus Garvey were among the Black nationalists and intellectuals with whom Angelou was impressed and inspired. As an orator for Black Nationalism and Pan-Africanism, Garvey espoused the Back-to-Africa Movement, which called for the repatriation of African Americans to their continent of origin, Africa. He believed America should remain white and Africa black. He started the Universal Negro Improvement Association (UNIA) with the goal of establishing a separate Black nation for African diaspora. Garvey had pride in the supremacy of African history, culture and race. His separatist philosophy inspired the Nation of Islam and the Rastafarian movement that aimed at putting African Americans on the road to self-independence and providing them with a superior culture and civilization (Sundquist, 1993).

However, the civil rights activist Du Bois considered Garvey an enemy of the Negro race in America due to his separatist philosophy. Du Bois wanted African Americans to stay in the United States and accept America as home. He co-founded the National Association for the Advancement of Colored People (NAACP) to advance justice and equality through social change for African Americans. Du Bois sought to improve both the African American condition and American culture as a whole. America, Du Bois asserted, is not home for people of Anglo-Saxon descent only. Rather, America is a multicultural nation accommodating people from different racial and cultural backgrounds (Du Bois, 1989). Du Bois recounted the history of African Americans with special focus on their unsung contributions to the American society. He expounded that African Americans unquestionably contributed to the early exploration of America, development of industry and agriculture, construction of railroads, conquests in the First World War and the Second World War, and enrichment of American literature and culture. Hence, one is American by virtue of his contributions to the American society, but not by virtue of race, color or national origin (Du Bois 2007).

The nuances of the two spectrums of Black nationalism inform the poetry of Angelou. Her poetry is fully interwoven with her life as a displaced African American woman yearning for a lost homeland, and enduring episodes of abuse and racial discrimination. Angelou grew up in a community, where the dichotomy of colors, genders, races and ethnicities prevailed; and through her poetry she has risen to become a point of consciousness for African Americans. She utilized nationalism as a "binding force" (Ghani, M., \& Bushra N., 2007, p. 101) to survive against colonialism and forge a Black identity. Her poetry expresses a passionate quest and struggle for the existence of "Black as a Published by Sciedu Press 
nation" (Ghani et al., p. 101) and for the formation of Black identity that is described as a "painful process of recalling and remembering her past which is broken and dismembered in fragments" (Ghani et al., p. 96). The most recurring themes in her poems are resistance and national consciousness, construct of the otherness, racial differences and social acceptance.

Angelou challenged the ethnocentric assumptions of the inferiority of the Black race through her poetry. She wholeheartedly believed in the potentials of Africans to overcome, triumph and rise above hostility, dire conditions and racial epithets. The confident optimistic tone with which Angelou spoke to the black and non-black seeks to disseminate love, hope, peace and sisterhood across the world. Angelou's poetry "expresses the dream and hope, desires and aspirations, joys and sorrows of African Americans" (Trivedi, 2016, p. 16). It demands equality, justice and peace not only for Africans but also for people of other races and ethnicities.

The theme of self-actualization permeates the poetry of Angelou in two respective aspects. One aspect concerns the degradation and dissolution of African cultures in the New World to which Africans came as enslaved people. The other aspect concerns reaffirming African American identity. The marginalization and inferiorization of African Americans, Angelou realized, are cultivated by mainstream American culture that needs to be reconstructed. Her poetry, which attaches positive attributes to blackness, seeks to awaken self-consciousness of African Americans "by encouraging them to preserve and celebrate their Black culture" (Du, 2014, p. 65). Any effort to recover self-consciousness of African Americans and restore Black identity, Angelou believed, must be coupled with a redefinition of blackness as "no disgrace but an honor because black is beautiful" (Du, p. 68). Angelou's poetry portrays working class African Americans with dignity, a positive self-image and strong self-awareness to counteract the stereotypical image of the debased black in mainstream American literature such as Stowe's Uncle Tom's Cabin. The new black, Angelou boasted, "accept their Black identity and revise the once zero images for themselves" (Du, p. 67). The new black was represented "not as an alienated but as a new and whole person who occupies a totally different social space" (Du, p. 67).

In "Africa", the speaker adopts a non-reconciliatory attitude that differs from that of Angelou. While Angelou emphasizes the capability of African Americans to overcome racism and social inequalities, and to assert their double consciousness, the speaker reproduces the separatist ethos of Black nationalism through a chauvinistic emphasis on the blackness and self-sufficiency of Africa. The whole poem is an extended metaphor comparing Africa to a beautiful Black woman mercilessly raped and robbed of her children The metaphor is intended to describe precolonial Africa as a heaven of peace and prosperity, colonized Africa as an abyss of ruin and misery, and postcolonial Africa as a hub of resistance and struggle to restore its glory and pride.

The speaker romanticizes precolonial Africa as an idyllic Eden, where the black used to live in prosperity and peace:

$$
\begin{aligned}
& \text { Thus she had lain } \\
& \text { sugar cane sweet } \\
& \text { deserts her hair } \\
& \text { golden her feet } \\
& \text { mountains her breasts } \\
& \text { two Niles her tears }
\end{aligned}
$$

The prosperity and beauty of Africa are signified by the figure of a Black woman whose hair is desert, feet are gold, breasts are two mountains, and eyes are the two tributaries of the Nile River. Africa, the speaker stresses, was not a desolate wasteland of helplessness and poverty. Africa got rivers, fertile lands, mountains and natural resources. Most importantly, Africa had skilled people to do mining and farming among other activities. In his perspective, Africa has had all the necessary potentials to be free, independent and self-sufficient. This accounts for the speaker's pride in Africa as suggested in the lines:

Thus she has lain

Black through the years.

Africa, the speaker proudly proclaims, is the motherland of the Black race. Such a proclamation uncovers the racial underpinnings upon which the world is divided. Historically speaking, Africa to ethnologists and nationalists has been black, and Europe white. The Black man living in Europe or America, and the White man in Africa are accordingly viewed and treated as an outsider. Africa, the speaker suggests, has been black in terms of race as well as culture. Thus, Africans should resist any attempt of assimilation, displacement or hybridization to maintain the homogeneity and purity of their race and culture.

The earlier sense of pride the speaker felt turns into anger and outrage at the White man for disrupting peace in the 
colonized Africa. The speaker tends to negatively represent the white as greedy, lustful and ferocious intruders, who invaded Africa with the mere intention to kill, loot and plunder:

$$
\begin{gathered}
\text { Over the white seas } \\
\text { rime white and cold } \\
\text { brigands ungentled } \\
\text { icicle bold } \\
\text { took her young daughters } \\
\text { sold her strong sons }
\end{gathered}
$$

The word "ungentled" signifies the transition of Africa from peace to turmoil and from hope to fear. White imperialists are condemned for raping the women, selling the men into slavery and stripping Africa of its resources. They as well sent missionaries to have Africans forsake indigenous religions and convert into Christianity:

$$
\begin{gathered}
\text { churched her with Jesus } \\
\text { bled her with guns. } \\
\text { Thus she has lain. }
\end{gathered}
$$

Implicit is the speaker's realization that the white relied on religion to justify imperial conquests in Africa and to disseminate western ideals and values. Any resistance to colonization on the part of Africans, the speaker claims, is met with extreme violence and repression.

The speaker's negative image of the white substantiates the racial prejudices and biases that he holds. The White man, for him, is an outsider coming overseas from an unknown world, driven by greed and lust. He is not what imperialists claim to be a benign selfless father figure devoting himself for the protection and civilization of his savage dependents. The Black man is, however, portrayed as a helpless victim of slavery, colonization, and missionization. He is not what he is claimed to be savage, vicious and homeless. Africa is where the Black man, whether in Europe, America or elsewhere, belongs. The Black man was forced to leave his homeland and adopt the more civilized languages, cultures and religions of his invaders. The image of the Black man as a victim is meant to exonerate Africans from any blame or responsibility for their part in slavery and colonialism. Africans, particularly tribal leaders and chiefs, had mercantile and cultural agreements with the imperial powers through which they sold their prisoners of war from neighboring or enemy tribes to European and American slave traders.

The speaker's tone in the third stanza changes from anger to hope and triumph. Postcolonial Africa is depicted as a strong Black woman luckily surviving the atrocities of colonization and slavery:

$$
\begin{aligned}
& \text { Now she is rising } \\
& \text { remember her pain } \\
& \text { remember the losses } \\
& \text { her screams loud and vain } \\
& \text { remember her riches } \\
& \text { her history slain } \\
& \text { now she is striding } \\
& \text { although she had lain. }
\end{aligned}
$$

The words "rising" and "striding" betoken the woman's journey from death to life and from captivity to freedom. Despite the attempts of impoverishment and suppression, the woman emerges stronger and more committed than ever to build a better future for her Black children. Realizing that she cannot break away from her "slain" history which informs her present as well as future, she does not allow her past to let her down. Rather, she utilizes it to turn losses into gains, defeat into triumph, and shame into pride.

In short, several chauvinistic inferences underlie Angelou's poem, the first of which is the conception of Africa as home or mecca of the Black race and culture. The speaker presumes that Africans in diaspora are alienated, disconnected and relegated to an inferior position in all walks of life. This presumption underpins the other chauvinistic inference that people of different races and cultures cannot peacefully coexist. The speaker also expresses a concern about the homogenizing effect of integration and assimilation on African American identity. African diasporas in the United States of America, the speaker fundamentally believes, should physically or imaginatively return to Africa or cling to their ethnic culture that serves as a bridge connecting them to their homeland of origin. 


\subsection{Mahmoud Darwish}

Darwish's poetry is saturated with the sentiments of anticolonial nationalism, which have emerged in colonies since the nineteenth century to demand an end to colonial rule and establishment of independent nation-states. As a displaced Palestinian writer, Darwish struggled against the Israeli Occupation of Palestine. He fought for the Palestinian cause by means of writing and politics. Politically, he has been an active member of the Palestine Liberation Organization (PLO) since 1973. Following his election to the PLO Executive Committee in 1987, he wrote the Palestinian People's Declaration of Independence, which President Yasser Arafat proclaimed in 1988. Yet, Darwish declared his resignation from the PLO in 1993 in protest against the Oslo Accords. He shared that antagonistic stance with his close friend and fellow citizen Edward Said (Ghannam, M. \& El-Zein, A. 2009).

The anticolonial ideals and attitudes Darwish tightly clung to found a vent in poetry. Darwish's poetry resonates the poetics of resistance literature, which his friend and fellow citizen Ghassan Kanafani first used to signify

a kind of literature originated in different parts of the world, out of the long confrontation between the nationalist movements and the imperialist colonialist interests. Instead of being a tool for expressing personal experiences, recollection of sweet memories and description of natural beauty, resistance literature tends to be the most powerful medium to exchange views, carry messages and even to theorize political parameters of liberation movements in various parts of the world (Al-Hudawi, 2003, p. 27).

Resistance literature is considered an extension of postcolonial literature for its attempts to rebut dominant ideologies and bring the racism and oppression of colonial powers to light. It is conceived as a vehicle through which the colonized can be empowered and given a voice. Resistance literature not only expresses the concerns and aspirations of the colonized people, but it also encourages them to engage in resistance movements. It is mainly intended to wage the natives' struggle for liberation, identity and physical existence in their homeland. It as well nurtures and sustains indigenous cultures, traditions and values that the colonizer seeks to wipe out. The epitome of resistance literature according to Kanafani is Palestinian literature that explores existential themes related to occupation, settlement, exile, identity and loss of homeland. (Jayyusi, 1992, p. 3).

Mahmoud Darwish's conception of national identity is borne out in his poetry. Identity for Darwish is pursuable through the language, land and culture of Palestine. Language for him is "home and self. It is outside of place and time" (Nofal, 2017, p. 68); and his poems make a homeland of words. The image of homeland as a woman or a mother in Darwish's poetry asserts interconnectedness between land and identity. He excessively referred to cities, villages, landscapes and fields in his homeland "to emphasize the historical, geographical and cultural entity of Palestinians" (Nofal, p. 70). Darwish's poetry also invokes emblems of the indigenous culture, customs and traditions "to which Palestinians could resort for stability and steadfastness" (Nofal, p. 72). Yet, Darwish identified himself as a Palestinian, an Arab and a human, thanks to his diverse cultural experiences in exile for most of his lifetime.

Search for identity and sense of the loss of land are important motifs in Darwish's poetry of resistance. Darwish attached Palestinian identity to the occupied land of Palestine in his early poetry to raise awareness of man's connection to land and to express an overt resistance and opposition to occupation and settlement construction in the Palestinian territories. The experience of refuge and displacement, which Darwish underwent, "has given birth, on the one hand, to his poetry of resistance and, on the other hand, to that strong inseparability of identity and land depicted tactfully in his poems" (Ahmed, H. Y., Hashim, R. S., Lazim, Z. M., \& Ravichandran V., 2012, p. 7). A sense of interdependence and interconnectedness between man and land is evoked when the effect of natural scenery in Palestine on the formation of Palestinian identity is examined in the poetry of Darwish.

Nature in Darwish's poetry is perceived as a form of resistance to colonialism. It is utilized as "a powerful form of resistance, which can be coined as green resistance or eco-resistance, to the colonization of his homeland" (Yahya, 2012, p. 82). That is to say, green poems instill green resistance in Palestinians. One prominent theme in the poetry of Darwish is interconnectedness between Palestinians and nature. Such nature-centered poetry shows how central nature is to Palestinian resistance, "nature appears as the center of resistance against the occupier of the poet's homeland. It also presages and supports the armed struggle of people and even joins the passionate condemnation of the colonial violence" (Yahya, p. 81). Nature-based images and symbols are accordingly used in the poetry of Darwish to evoke eco-resistance.

Many poems by Darwish reflect upon refugees' feelings of alienation and dislocation in exile. The words of Darwish's poems evoke homesickness and homeliness in the mind-set of Palestinians. Forms of resistance for 
Darwish varied from war to words, but he mainly relied on political activism and literary words in his resistance to the Israeli Occupation of his homeland. The historical and political story of Palestine is narrated using "expressive symbols and images that give an insight into the relationship between Israel and Palestine" (Al Areqi, 2013, p. 33). The tone of the speaker in Darwish's poetry conveys "anger, enthusiasm and bravery. The voice seems strong and the words are convincing and containing the power that is sufficient to shake the person who hearing them. The words reflect the pains and sacrifices of the owner of the land" (Al Areqi, p. 36). Darwish's poetry in exile uses powerful images and words to express homesickness and anticolonial attitudes and to give voice to his stateless people.

The speaker in Darwish's "I come from There" is not less chauvinistic than the speakers in Kipling and Angelou's poems. The poem typifies the anticolonial emphases on the homogeneity of nations and cultures, and the legitimacy of resistance to occupation and settlement. The speaker asserts the Arab identity of Palestine and its people, and casts Israelis as outsiders and intruders. He maintains that Palestinians were not born homeless:

\section{I come from there and I have memories}

Born as mortals are, I have a mother

And a house with many windows,

I have brothers, friends,

The collective memories of exile, dispossession and occupation, which bring all Palestinians - whether in Israel, the West Bank, Gaza Strip, or in refugee camps - together, have been perpetuated through the multitude of images and narratives Palestinian writers collected and called up in their works. Though the speaker in Darwish's poem lives in diaspora as the use of the adverb of place "there" suggests, he retains the memory of the homeland he originally descended from. He nostalgically reflects upon the memories of his father and mother, brothers and sisters, and friends in Palestine before Israelis sent him into exile. He remembers the house, where he was born, brought up and freely lived. The large number of windows his house had signifies the unfettered freedom and independence Palestinians used to enjoy before the Israeli Occupation of their land.

However, Israelis, whose ancestors lived in diaspora around the world, are alien to the land of Palestine. The Israeli existence in Palestine, the speaker claims, not only disrupted the state of peace Palestinians had but also dispossessed Palestinians of their land and freedom:

I walked this land before the swords

Turned its living body into a laden table.

The poem excessively uses the first person pronoun "I" in subjective and genitive cases to entail that Palestine is historically an Arab nation populated by Palestinian Arabs. The speaker relates that while his ancestors have inhabited and cultivated the land of Palestine down through the ages, Israelis have had no existence in Palestine until the State of Israel was established in 1948. In his belief, Israel does not act as a typical imperial power that seeks to civilize, missionize and enlighten its colonial subjects. Rather Israel was established as a national home for Jews in Palestine. Hence, building settlements, admitting displaced Jews from Europe and elsewhere into Palestine, and establishing an apartheid regime to segregate and marginalize Palestinians were far more important than any humanitarian, ideological or ethical considerations. It is denoted that Israelis applied violence to fulfill the settlement project, which has necessarily led to the fragmentation of Palestinian identity and land. Palestine is perceived as a "laden table" or feast, and the Palestinian territories as the different types and flavors of foods and drinks served on it. Israelis relied on the military force to occupy the territories that best meet their settlement needs, and to devastate the others. The voraciousness of Israelis to devour the land of Palestine is compared to that of seagulls:

Mine is the wave, snatched by sea-gulls,

Palestine is depicted as a wave from which Israelis are rapaciously plundering and devouring fish.

Realizing that Israelis are the plunderers and usurpers of his national and ancestral homeland, the speaker resists any possibility of co-existence or peace between Israelis and Palestinians:

I learnt all the words worthy of the court of blood

So that I could break the rule.

I learnt all the words and broke them up

To make a single word: Homeland.....

The word "single" denotes that the speaker does not recognize Palestine as a bi-ethnic homeland for Israelis and 
Palestinians. Instead, he wants to reclaim Palestine as home for Palestinians only. Words are the stones or bullets the speaker hurls at Israelis to liberate his homeland. Language helps him resist conformity to the colonial rule and discourse, and draw attention to the destructive impact of the Israeli Occupation on the land, culture and people of Palestine. Hence, he speaks about the homesickness of Palestinians in diaspora and refugee camps:

I come from there. I render the sky unto her mother

When the sky weeps for her mother.

And I weep to make myself known

To a returning cloud.

It is through writing that the speaker returns displaced Palestinians, whom he likens to a crying sky or cloud, to their motherland. His writing also entitles Palestinians to control their land and natural resources:

Mine is the moon at the far edge of the words,

And the bounty of birds,

And the immortal olive tree.

The fertile fields, where birds breed and feed, and the timeless olive trees growing there signify the sanctity of the land of Palestine, which the Israeli Occupation has shattered.

\section{Conclusion}

Examining the discourse of nationalism, which the selected poems cultivate, reveals that the speakers adopt chauvinistic attitudes exasperating existing dichotomies of self and other. As a proponent of imperialism, Kipling reaffirmed the superiority of the White race on the basis of social Darwinism. The White man, he believed, is naturally fitter to rule the world, and other races should recognize their innate inferiority and appreciate the efforts imperialists exerted to save them from savagery. In like manner, Angelou reproduced the chauvinistic presumptions of Black nationalism in her poem. The speaker in her poem proclaims Africa as the homeland of the Black race, and takes pride in the Black race and its cultural heritage. The inferiority of the Black man, Angelou believed, is of a social but not a natural kind. The Black man in her perspective has been civilized, prosperous and self-sufficient over the ages, but slavery and colonization rendered him inferior and helpless. Darwish's poem, which echoes the chauvinistic tenets of anti-colonial nationalism, serves as a prototype of resistance against the Israeli Occupation of Palestine and the displacement of Palestinians. Israelis are viewed as outsiders and intruders who dispossessed and displaced the people of Palestine. The occupied land of Palestine, the speaker asserts, should be restored and Palestinians in refugee camps and diaspora should return to their ancestral homeland.

\section{References}

Ahmed, H. Y., Hashim, R. S., Lazim, Z. M., \& Ravichandran, V. (2012). Identity and Land in Mahmoud Darwish's Identity and Land in Mahmoud Darwish's Selected poems. An Ecopostcolonial Reading. International Journal of Applied Linguistics and English Literature, 1(6), 7-19. https://doi.org/10.7575/ijalel.v.1n.6p.7

Al Areqi, R. M. (2014). Home, Homeliness and Search for Identity in Mohmoud Darwish's Poetry. International Journal of English Language Teaching, 1(1), 32-41. https://doi.org/10.5430/ijelt.v1n1p32

Al-Hudawi, S. (2003). Re-discovering Identity: A Study on the Theme of Resistance in Ghassan Kanafani's Selected Novels. M.A. Thesis. International Islamic University, Malaysia. https://doi.org/10.2139/ssrn.2374778

Angelou, M. (1975). Oh Pray My Wings Are Gonna Fit Me Well. $2^{\text {nd }}$ Volume. USA: Random House. Bayoumi, M., \& Rubin A. (2000). The Edward Said Reader. New York: Vintage Books.

Darwish, M. (1960). I Come from There. In PoemHunter. Retrieved August 5, 2020, from https://www.poemhunter.com/poem/i-come-from-there/

Diamond, I., \& Quinby L. (1988). Feminism and Foucault: Reflections on Resistance. Northeastern University Press.

Du Bois, W. E. B. (2007). The Gift of Black Folk: The Negroes in the Making of America. New York: Oxford University Press.

Du Bois. W. E. B. (1989). The Souls of Black Folk. New York: Penguin Books.

$\mathrm{Du}$, J. (2014). Exploring the Theme of Self-Actualization in Maya Angelou's Poetry. English Language and Literature Studies, 4(3), 65-70. https://doi.org/10.5539/ells.v4n3p65 
Ghani, M., \& Bushra, N. (2007). Race, Feminism and Representation: An Inquiry in to Maya Angelou's Poetry. International Research Journal of Arts \& Humanities, 35(1), 95-106.

Ghannam, M., \& El-Zein, A. (2009). Reflecting on the Life and Work of Mahmoud Darwish. CIRS Brief, No. 3, George Town University: School of Foreign Services in Qatar.

Ghiasvand, F., \& Bahman, Z. (2014). Hybridity: The Effect of Imperialism in Rudyard Kipling's Kim. Journal of Novel Applied Sciences, 3(S2), 1693-1699.

Hanane, G. (2019). Imperialism and English Literature: Case Study of Rudyard Kipling's Kim. M.A. Dissertation. Elchahid Hamma Lakhdar University, Eloued.

Hassan, I. (1955). The Problem of Influence in Literary History. American Journal of Aesthetics and Art Criticism, 14(1), 66-76. https://doi.org/10.2307/426642

Jayyusi, S. K. (Ed.). (1992). Anthology of Modern Palestinian Literature. New York: Colombia University Press.

Kipling, R. (1940). Africa. Rudyard Kipling's Verse. New York: Garden City, pp. 321-323.

Nofal, K. H. (2017). National Identity in Mahmoud Darwish's Poetry. English Language and Literature Studies, 7(3), 66-77. https://doi.org/10.5539/ells.v7n3p66

Offer, J. (2000). Herbert Spencer: Critical Assessments, Volume 2. Taylor \& Francis.

Perry, M., Chase, M., Jacob, J. R., Daly, J. W., \& Von Laue, T. H. (Eds.). (2013). Western Civilization: Ideas, Politics, and Society. United States of America: Cengage Learning.

Šumberová, K. (2006). British Imperial Experience as Reflected on Different Identities in Kipling’s Novel Kim. B. A. Thesis. Masaryk University in Brno.

Sundquist, E. J. (1993). To Wake the Nations: Race in the Making of American Literature. Cambridge, MA: Belknap of Harvard UP.

Trivedi, D. (2016). Rising from the Dust: A Study of Maya Angelou's Poetry. International Journal of English Research, 2(2), 14-17.

Yahya, H. (2012). Eco Resistance in the Poetry of the Arab Poet Mahmoud Darwish. The Southeast Asian Journal of English Language Studies, 18(1), 75-85.

\section{Copyrights}

Copyright for this article is retained by the author(s), with first publication rights granted to the journal.

This is an open-access article distributed under the terms and conditions of the Creative Commons Attribution license (http://creativecommons.org/licenses/by/4.0/). 